\title{
SIMULATION OF COST DRIVEN VALUE STREAM MAPPING
}

\author{
Jordan, E. * Berlec, T. ${ }^{* *}$; Rihar, L. ${ }^{* *} \&$ Kusar, J. .,\# \\ ${ }^{*}$ Kekon d.o.o., Grajski trg 15, 8360 Žužemberk, Slovenia \\ ** University of Ljubljana, Faculty of Mechanical Engineering, Aškerčeva 6, 1000 Ljubljana, Slovenia \\ E-Mail: janez.kusar@fs.uni-lj.si ( ${ }^{\#}$ Corresponding author)
}

\begin{abstract}
Value stream mapping (VSM) is based on an analysis of the times required to carry out production processes throughout the customer-manufacturer-supplier logistics chain. The goal of VSM is to identify wastes and eliminate them, thereby increasing the added value of a product. The paper presents an extension of the VSM concept which is based on determining the costs associated with the necessary operations and determining, based on said costs, the total costs of the entire production process. When eliminating those activities that represent waste, we can, by simulating the total costs, determine the contribution of the implemented measure to the reduction of lead time and, above all, the reduction of costs and thus the economic efficiency of the production process. For the presentation, by simulating the identified cost effects of the anticipated changes, we can calculate the leanness cost index and, using portfolio analysis of the leanness of the production system, analyse the effects. The application of the proposed methodology is shown in the case of transition from individual to lean and agile series production of ceramic capacitors.

(Received in June 2020, accepted in August 2020. This paper was with the authors 1 week for 1 revision.)
\end{abstract}

Key Words: Lean Production, Value Stream Mapping (VSM), Simulation, Leanness Cost Index, Portfolio Analysis of Production System Leanness

\section{INTRODUCTION}

Lean thinking usually refers to 3 important areas of business: lean management, lean product and process development, and lean production.

If we look at production processes in detail, the processes can be, in terms of leanness, divided into those that add value (value added), those that do not add value, but are absolutely necessary for the implementation of processes that add value (necessary non-value added), and those that contribute nothing to the added value of the product (non-value added), but consume time, resources, space and bind capital. The latter is simply called wastes.

Wastes can be divided into strategic, organizational and operational wastes. To eliminate waste at the strategic level, it is important for the management to choose the right strategies regarding the type and quantity of products that can be sold in the market, and select the right processes that enable development and manufacturing that are of interest to the customer in terms of quality and price. Organizational waste is mainly due to the wrong organizational structure of the company, poorly defined and non-transparent business processes, lack or underutilization of production resources, poorly selected technology and lack of knowledge or experience of middle management. Operational waste is related to hyper production or premature production, waiting, storage, transport, work process, movement and production of defective products.

Value stream mapping is most often used for waste analysis, which systematically describes the entire logistics chain of the production process from suppliers, production, storage to delivery to the customer.

Value stream mapping is based primarily on the analysis of time losses. However, a time loss does not indicate what the consequence of the waste is expressed in money. For example, the loss of one working day due to waiting at the disposal location before the next operation is, 
in terms of money, significantly lower than the loss of one working day due to too long machine set-up time. So, in addition to time analysis, it is necessary to perform a cost analysis of wastes. Even in practice, to eliminate waste is not enough, it is increasingly important to create added value.

The paper will show the method of expanding the classic VSM with a cost analysis of the entire production process. By using simulation of different scenarios of waste elimination, the cost effects of the transition to lean production can be determined by calculating the leanness cost index and using a portfolio analysis of the production system leanness.

\section{LITERATURE REVIEW}

Based on the latest literature review for the use of value stream mapping and simulation regarding the non-value added and value-added time, the following papers dealing with this topic were found:

As described in [1], VSM is a visualization tool for the supply chain and value stream, based on the Toyota Production System, and is of great help in successfully implementing a lean system. VSM is a mapping tool for a set of activities (value added, non-value added and necessary non-value added) needed to bring the product from a raw material to a finished product, which the customer requires [2]. Heravi and Firoozi [3] confirmed that the ultimate goal of lean philosophy is to eliminate or decrease wastes and deliver value to the customer. Often the Poka Yoke methodology is used in production processes and has become a synonym for error prevention, which is also one of the major wastes, since errors are prevented before reaching the customers [4]. According to [5], lean scheduling is conceptually similar to lean manufacturing and revolves around elimination of wastes, continuous improvement, total preventive maintenance and quick changeover. The implementation of lean in job shop reflected that lean scheduling is possible in job shop as well and can bring positive impact on manufacturing activity. It may be helpful to reduce the long lead times with reduction in nonprocessing times and implementation of 'One piece flow'. Kuhlang et al. [6] stated that the interaction of Value Stream Mapping and the Hybrid Optimisation of Added Value at different levels of detail consideration contributes to the identification, elimination and avoidance of waste and thus leads to a design of efficient and effective processes. The joint mutual benefit of the combined application arises from the increase in productivity, from the standardisation of processes, from the reduction in lead time/inventory and from the accurately determined times; it also enables and ensures the predictability and the capability to assess the target status.

Gunduz and Naser [7] have introduced and developed a concept to calculate the cost of Value Stream Mapping on a weekly basis. This technique can be utilized to understand the construction progress status and future expectations. Moreover, it can be used to calculate the cost of similar projects for tendering purposes. The paper attempts to address the application of Value Stream Mapping to a real-life problem of an underground pipeline project. It analysed the improvement of value-added times and reduction in non-value-added times compared with the cycle time. They studied the reduction opportunity in total lead time.

According to [8], small and medium scale enterprises are under a constant pressure to improve the product quality in order to meet customer requirements. They stated that the LeanKaizen using VSM was found as an effective technique to reduce the cost.

Carmignani [9] suggested a new methodology called Scrap Value Stream Mapping (SVSM) which combines the concepts from the standard VSM approach with other tools deriving from World Class Manufacturing and Lean Production. In particular, the framework is structured to analyse the accounting and the physical stream of the Supply Scrap Management Process (SSMP) in order to optimise them, by proposing implementable improvements. Furthermore, 
the SVSM proposes a monitoring methodology to keep two components of non-capital carrying costs that are affected by SSMP, namely Storage Space costs and Inventory Risk costs low.

The presented simulation model from Onofrejeva et. al. [10] for the qualitative approach to management decisions related to the evaluation of key parameters (productivity and throughput of the manufacturing system) was based on the simulation results on optimizing the production capacity by selecting constrains, with the goal to increase productivity and setting the production to maximize sales profit using the Simplex method.

The Theory of Constrains (TOC) is another widely known management concept used also by the study of Urban [11] who concluded that, if a company wants to meet a new level of productivity, the manufacturing system needs to have an adopted and improved solution mix consisting of a variety of means and methods. As described in [12], the main implementation weakness of production management methods as Lean, Six Sigma or TOC lies with over focussing on particular method, so those methods are usually used solitary, and the complex approach is usually underestimated. This can be changed only with changing the way of thinking within all levels of company's management. The authors have been focussing on the use of basic principles of process thinking connected with design, technology and manufacturing logistics with emphasizing the role of standardization. They concluded that the process thinking development should be the creation of a methodology to support the systematic implementation of process thinking and process-oriented methods at all levels of the company.

It is not only the throughput time that is important, but also the production system availability shown by Zhou et al. [13]. By flexibly changing the production configuration, the improvement of system availability is possible [14] using the genetic algorithm for efficient optimisation by changing the production configuration (workers, machines, buffers and transporter allocations). Based on the research by [15] contingency factors in terms of company size, batch size, product complexity, included as control variables in analyses, proved insignificant for technologies' use and their effect on profits before tax, decrease in the scrap rate, material and staff costs. On the other hand, advanced manufacturing technology has impact on material consumption, scrap rate and profits, but not in a positive hypothesised relationship.

In the paper [16] a business planning model with feedback was presented, were the model includes planning, monitoring and harmonization of business operations which is also appropriate for unstable conditions, regarding the essential influences from the business environment, thus adapting the company's operations.

Sremcev et al. [17] presented an application of VSM and discrete event simulation to improve the company's performance new system design in terms of accepted quotations, resource utilisation, delivery time, work in process, non-value-added time and number of required operators.

The costs in connection with VSM were most comprehensively recorded by Gracanin et al. [18], particularly the costs of material, labour and waiting and the course of costs was shown in a cumulative histogram. The advantage of such presentation is that a time-dependent cumulative cost generation can be presented. In this way, it is possible to show the cost and time effects of measures implemented on the value flow.

Based on this literature review, we came to a conclusion that the cost aspect of the VSM influence is not well studied or developed, so this paper proposes a model based on the VSM methodology with simulation based on the cost aspect as shown in the next chapter.

\section{METHODOLOGY}

The cost analysis of waste according to VSM should include all costs that occur in the production logistics chain of one product. The costs incurred are divided into costs that add value, costs that enable the creation of added value and costs that represent a waste. 


\subsection{Costs and VSM}

In the following, the cost analysis will only include those costs that relate to activities in the production logistics chain of a product and represent a significant share of costs in the cost of the product.

The costs of activities relating to the added value of a work item $i$ include costs of material (price at the supplier's in $€ /$ piece) and costs of implementation of necessary technological operations at workplaces.

$$
c_{V A i}=c_{M i}+\sum c_{O i, j}
$$

$c_{V A i}-$ costs that represent added value,

$c_{M i}-$ costs of material at the supplier for the work item $i$,

$\sum c_{O i, j}$ - sum of costs of performing all technological operations $j$ on the work item $i$.

Reducing the costs of performing technological operations is achieved only by improving the manufacturing processes for carrying out technological operations, which is associated with larger or smaller investments.

Costs of activities that do not add value to the work item $i$ but are absolutely necessary for the implementation of production.

$$
c_{N N V A i}=\sum c_{T i}+\sum c_{S i, j}
$$

$c_{N N V A i}-$ costs that do not add value to the work item $i$ but enable added value,

$\sum c_{T i}-$ sum of transport costs of the work item $i$,

$\sum c_{S i, j}$ - sum of preparation costs (set up time) on an operation $j$ for work item $i$.

The costs of internal transport are minimized by optimizing the arrangement of workplaces so that the workplaces with the highest flow of work items are as close together as possible. However, the costs of work preparation on an operation $j$ for work item $i$ can be minimized by using the SMED method.

Costs of activities that do not add value and are considered to be wastes.

$$
c_{N V A i}=c_{w i}+\sum c_{L i, j}+c_{B i}
$$

$c_{N V A i}-$ costs that do not add value to the work item $i$,

$c_{w i} \quad$-warehousing costs (input, output),

$\sum c_{L i, j} \quad$ - sum of waiting costs of the work item $i$ before and after operation $j$,

$c_{B i}-$ cost of binding capital in the work item $i$.

Warehousing costs represent the costs of using warehousing areas and include: operating costs, depreciation, insurance, handling of work items. They depend on the selected type of warehousing (e.g. jerky inflow, steady outflow, with or without safety stock) and policy of ordering work items.

Waiting costs which represent the use of storage areas and unnecessary additional handling can be reduced by choosing a suitable system for operational production planning (such as scheduling algorithms, priority rules, KANBAN, CONWIP) and introducing the FIFO lines, milk run system and supermarket).

The cost of bound capital depends on the interest rate and the retention time of the work item in the production process.

The total costs of a unit of a work item $i$ can be calculated as follows:

$$
\sum c_{i}=c_{V A i}+c_{N N V A i}+c_{N V A i}
$$

The efficiency of the production process can be defined by the generated profit, i.e. by a difference between the selling price $S P_{i}$ and the total cost of the work item $i$. Thus, the costeffectiveness coefficient of the $P E_{c}$ production process equals:

$$
P E_{c i}=\left(S P_{i}-\sum c_{i}\right) / S P_{i}
$$


Based on the calculated cost-effectiveness index and the known index of overall equipment efficiency $O E E$, the leanness of a production process can be determined using the portfolio analysis [19] (Fig. 1).

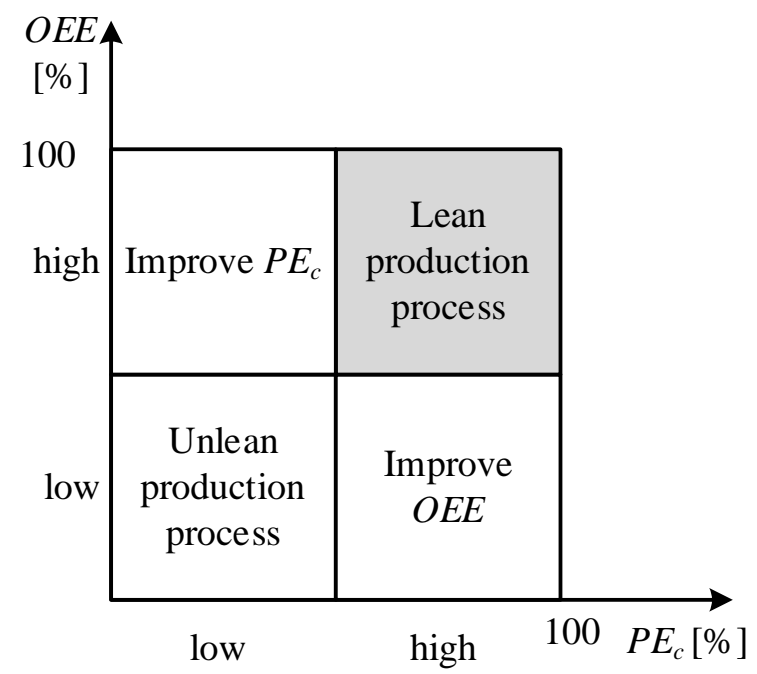

Figure 1: Portfolio analysis of production process leanness.

\subsection{Simulation of the impact of changes to achieve leanness}

Before deciding to make changes aimed at increasing leanness or at eliminating waste, which is usually anticipated after the implementation of the VSM existing state (AS IS state), the company's management must set clear goals and criteria to be reached by the planned changes. These goals are influenced by both the external (buyers, suppliers, environment) and internal (technological possibilities, products, space, capacities, financing ability) factors. The process of transition from the existing state, such as individual production, to a target state, such as serial lean and agile production, can be carried out in two ways:

- by introducing small changes based on the principle of continuous improvement, which means that the goals are approached gradually and usually with smaller investments, or

- by introducing radical changes associated with larger investments, where final (ideal) goals are first attempted to be reached, and only then the goals (if necessary) are gradually reduced, depending on whether the own price of the work items can sustain a large investment.

In the presented methodology we decided for a simulation based on the calculation of the efficiency cost index and the portfolio analysis, so we can opt for the second way (Fig. 2).

The basis for preparing a simulation programme is the VSM which shows all the states of the production process and the relationships between them. Since VSM gives only time values for individual activities, the simulation programme must contain all the mathematical relations for calculating the individual costs of operations and thus the total costs of the entire logistics chain (Fig. 3).

This allows us to continuously check the total costs after a certain change has been introduced. It has namely been established that the times of duration of an activity and the final relationship (time efficiency) between the times that add value or allow it and the lead time do not reflect the real-time state.

For instance: all wastes are eliminated in the process and at the same time the processes are improved and shortened, but when the time efficiency of the process is calculated, a worse result is obtained compared to the result from before the change has been introduced. This, in turn, dictates a need to introduce and calculate the cost-effectiveness of the production process. 


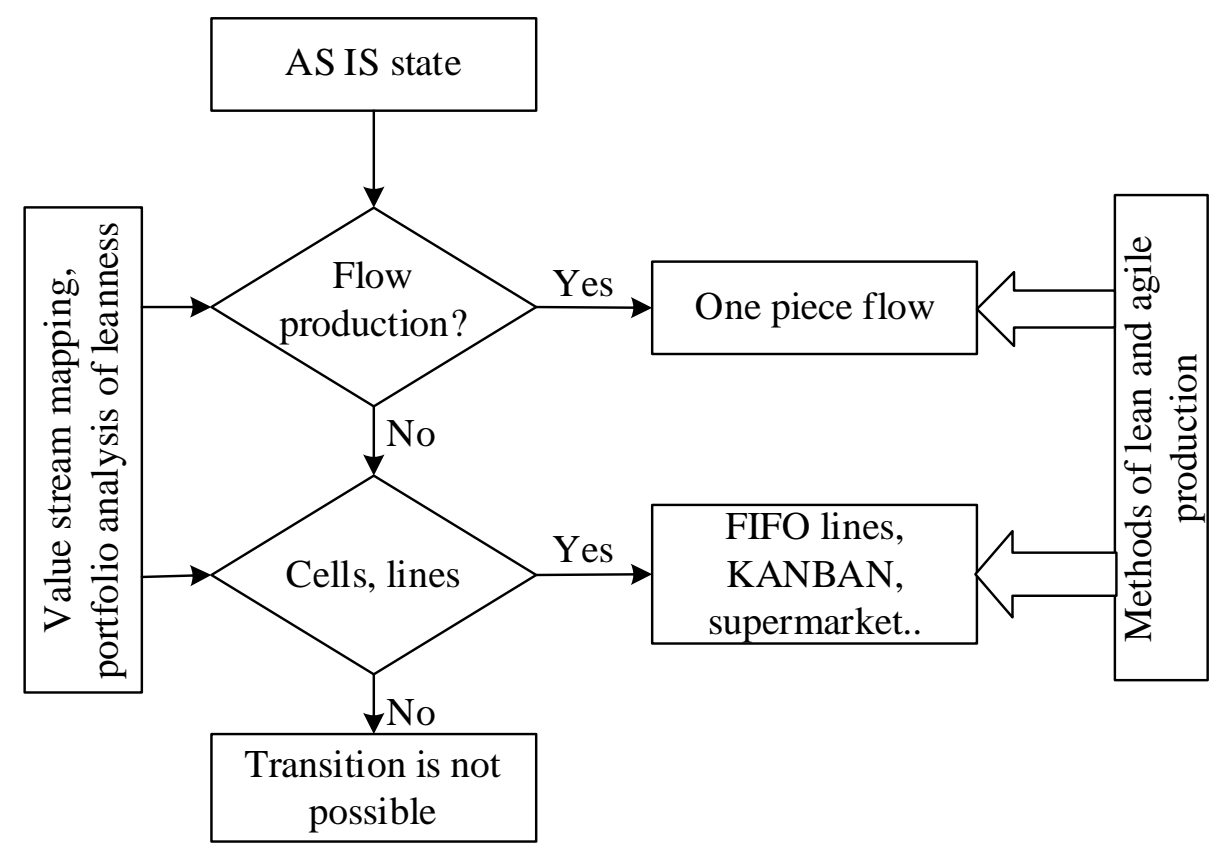

Figure 2: Transition from the existing state to a target state of a production process.

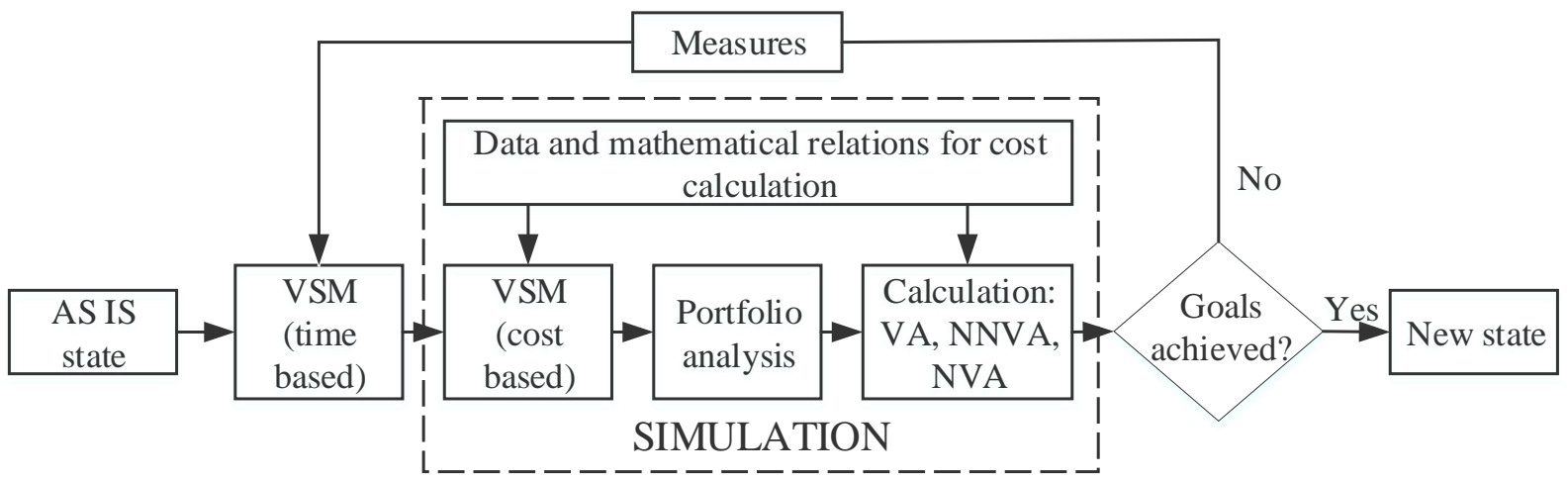

Figure 3: Simplified simulation model.

\section{CASE STUDY}

We will look at the simulation of a transition from the existing state to a target state on an example of transition from individual production to series lean and agile production. We will focus on the case of production of ceramic capacitors, which the company now produces in smaller quantities (1500 pieces/month), yet there is a possibility of a large increase in the quantities of up to 80,000 pieces per month in the future.

The goal of the company's management is to make a transition from the current individual production of a workshop type to series lean and agile production. As a measurable goal, the company determined that the economic efficiency index of the new PEc production method should be more than 0.5 and the product lead time should be less than 15 working days.

The company performed an AS IS VSM analysis for this product with proposed measures for the TARGET state, i.e. the transition to series lean and agile production. Based on the portfolio analysis of the current state (Fig. 2), the company decided to first determine what the economic impact would be if all the planned measures were taken to approach the flow production and what measures could be taken to opt for line production or cell production. However, it should be borne in mind that in the future the production of significantly larger quantities is expected and that the selling price will probably have to be drastically reduced, otherwise the company will not be competitive in the market. 
The company made an in-depth analysis of the VSM results and possible measures for improvement and thus prepared a simulation programme and data for cost efficiency simulation and portfolio analysis. First, the AS IS state was analysed and then, with numerous iterations of the simulation, the possibilities of transition to flow or cell or line production. The VSMbased cost simulation showed how much each improvement contributes to the cost effect of production.

Table I shows the data that we need to simulate the cost efficiency of a transition from the existing - AS IS state to a desired new state and part of calculated values.

Table I: Data for the implementation of simulation and partial results.

\begin{tabular}{|l|c|c|c|}
\hline \multirow{2}{*}{ Name of data } & \multicolumn{3}{c|}{ Values of data } \\
\cline { 2 - 4 } & AS IS state & Flow production & Cell or line prod. \\
\hline Produced quantity [pieces/month] & 1500 & 80,000 & 80,000 \\
\hline Lead time (from VSM) [Wd] & 73.85 & 7.3 & 9.12 \\
\hline Lead time without processing, preparation [Wd] & 72.77 & 7.06 & 8.88 \\
\hline Sum of processing times [min] & 18.22 & 2.34 & 2.34 \\
\hline Sum of preparation times [h] & 7.51 & 1.67 & 1.67 \\
\hline Transport path [m] & 888 & 159 & 233.8 \\
\hline Investment [€] & 0 & $1,163,800$ & 113,800 \\
\hline Depreciation cost - 3 years [€/piece] & 0 & 0.448 & 0.044 \\
\hline Selling price [€/piece] & 11 & $11 / 4$ & $11 / 4$ \\
\hline Number of operations needed & 54 & 32 & 32 \\
\hline Number of workplaces & 23 & 16 & 16 \\
\hline Material purchase price [€] & 0.5 & 0.5 & 0.5 \\
\hline Cost of warehousing + stocking [€/piece, $\mathrm{Wd}]$ & 0.00034 & 0.00040 & 0.00040 \\
\hline Workplace cost [€/h] & 30 & 30 & 30 \\
\hline Machine cost [€/h] & 17.8 & 17.8 & 17.8 \\
\hline Worker cost [€/h] & 12.2 & 12.2 & 12.2 \\
\hline Walking time [min] & 20.72 & 3.71 & 5.46 \\
\hline Transport cost [€/piece] & 0.0009 & 0.00001 & 0.00002 \\
\hline Cost of technological operations [€/piece] & 9.11 & 1.17 & 1.17 \\
\hline Preparation cost [€/piece] & 0.15 & 0.001 & 0.001 \\
\hline Cost of warehousing + stocking [€/piece] & 0.025 & 0.0028 & 0.0036 \\
\hline Capital binding interest rate [\%] & 3 & 3 & 3 \\
\hline Total cost [€/piece] & 10.37 & 2.22 & 1.82 \\
\hline
\end{tabular}

\subsection{Portfolio analysis of the AS IS state}

Using the proposed methodology, we wanted to determine the cost-effectiveness of the AS IS state. The data from Table I (column 2) were used in the simulation programme and it was established that the cost-effectiveness index of the production process is:

$$
P E_{\mathrm{ci}}=\left(S P_{i}-\sum c_{i}\right) / S P_{i}=(11-10.26) / 11=0.067
$$

For the portfolio analysis, we also need the overall equipment efficiency $O E E$, which is already monitored in the company by means of the production IS system (Manufacturing Execution System) and for the AS IS state the OEE is 0.54. Based on these two data, we can make a portfolio analysis of the AS IS state which is shown in Fig. 4.

Based on the portfolio analysis of the AS IS state, it can be concluded that the production process is not lean. However, since the $O E E$ more than 0.5 , it is reasonable to adopt further measures that will increase the cost efficiency of the production process $P E_{c}$ for the product in question. We decided to first check whether the flow production would be cost-effective. 


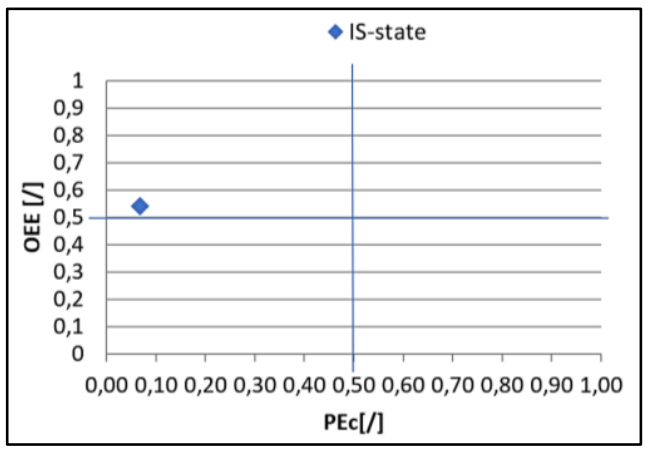

Figure 4: Portfolio analysis for the AS IS state.

\subsection{Portfolio analysis of flow production}

The goal set by the company is to achieve a lead time of less than $15 \mathrm{Wd}$ (working days) at an estimated quantity of 80,000 pieces/month and to achieve an index of economic efficiency of production $P E_{c i}$ more than $50 \%$, which would already mean lean production at the existing $O E E=0.54$. It should be noted that the selling price of the product will have to be reduced from $11 € /$ piece to $4 € /$ piece.

In order to achieve the stated goals, the company planned to implement the following measures based on the prepared TARGET VSM analysis:

- shortening setup times and cycle times on some operations using the SMED method,

- standardization of quantities and procedures in order to achieve a uniform material flow,

- shortening transport paths by relocating machines adapted to the process,

- elimination of all inter-operational stocks,

- investment in new machines to reduce the number and time of implementation,

- introduction of automation,

- redesign of the product design to reduce the number of operations,

- introduction of FIFO lines, 5S and Poka Yoke systems.

For the measures envisaged in individual operations of the production process, it is necessary to determine how much they contribute to the improvement of the cost efficiency of the production system. First, we undertook the simulation of the effects of waste management measures, i.e. the activities that do not add value. Then we started to change the technological process, standardizing the processes and introducing the necessary automation of technological and transport operations.

We found that the introduction of flow production would significantly reduce the lead time (to $7.3 \mathrm{Wd}$ ) and reduce costs (to $2.22 € /$ piece).

When calculating the cost efficiency index, we took two possible selling prices into account, the existing one ( $11 € /$ piece) and the worst-case scenario (4€/piece), and calculated the cost efficiency of the production process, first for the unchanged selling price (11 €/piece):

$$
P E_{c i}(11 €)=\left(S P_{i}-\sum c_{i}\right) / S P_{i}=(11-2.22) / 11=0.8
$$

and then for the selling price at most unfavourable conditions in the market (4€/piece):

$$
P E_{c i}(4 €)=\left(P C_{i}-\sum c_{i}\right) / P C_{i}=(4-2.22) / 4=0.44
$$

Based on the analysis of improvements in technological operations in the company, the $O E E$ is estimated to increase to at least 0.65 . The portfolio analysis of the flow production state is shown in Fig. 5.

The lead time is found to be shortened to $7.3 \mathrm{Wd}$ (the target was less than $15 \mathrm{Wd}$ ). According to the index of economic efficiency of production, it can be concluded that the set selling price has achieved the set goal (more than $50 \%$ ), but not with a possible reduced selling price. 


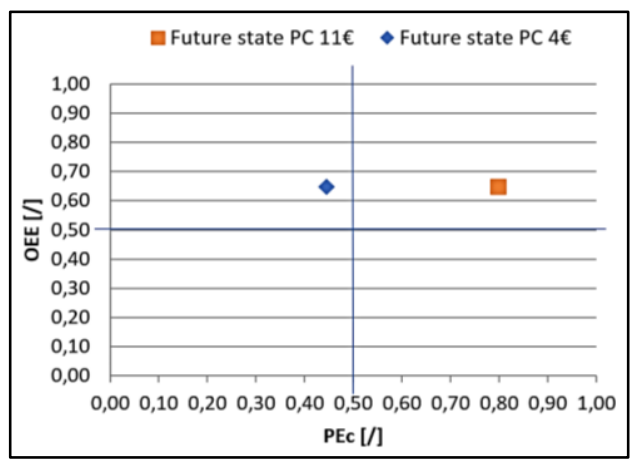

Figure 5: Portfolio analysis for the case of flow production (for $P C$ is $11 €$ and $4 €$ ).

The reason is that the transition to flow production would be associated with large investment funds, which would have a significant impact on the total cost of the product through depreciation. The calculation using the break-even point method showed that the investment in flow production would be profitable only at an output of 15,600,000 products per year $(1,300,000$ products per month).

Since such quantities are impossible to produce, we decided to perform a simulation for the case of a transition to cell or line production without full automation and expensive machines.

\subsection{Portfolio analysis of cell or line production}

In this analysis, we decided to introduce into production, in addition to FIFO lines, also KANBAN and the supermarket principle, which are characteristic of cell or line production.

The goals of production renewal remain unchanged, i.e. to achieve a lead time of less than $15 \mathrm{Wd}$ for 80,000 pieces per month and to achieve an index of economic efficiency of production $P E_{c i}$ more than $50 \%$. Due to the high investment in flow production, it was analysed which investment costs can be waived in order to still achieve the set goals.

It was found that the investment can be reduced by as much as $90 \%$ and we will still be able to produce a quality product. There are still plenty of reserves in terms of lead time and it can be increased if necessary. Above all, we retained all measures aimed at eliminating wastes. The simulation data are shown in Table I (column 4).

The calculation of the cost-effectiveness index of the production process at the unchanged selling price $(11 € /$ piece $)$ is:

$$
P E_{c i}(11 €)=\left(S P_{i}-\sum c_{i}\right) / S P_{i}=(11-1.82) / 11=0.83
$$

and for a possible selling price in the most unfavourable market conditions (4 €/piece]:

$$
P E_{c i}(4 €)=\left(S P_{i}-\sum c_{i}\right) / S P_{i}=(4-2.22) / 4=0.55
$$

Presumably, the $O E E$ will still remain at 0.65 . The portfolio analysis of the state that would allow for cell or line production is shown in Fig. 6.

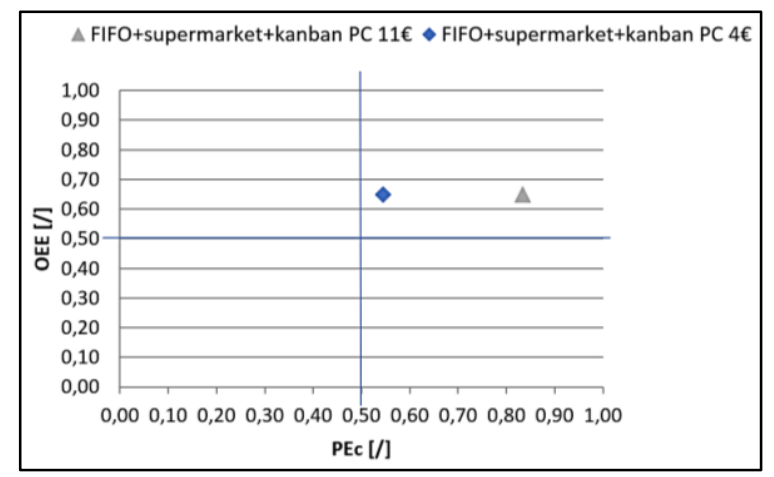

Figure 6: Portfolio analysis for the case of cell or line production. 
It can be established that the lead time has increased to $9.12 \mathrm{Wd}$ compared to the flow production, which is still less than the target value of $15 \mathrm{Wd}$. Regarding the economic efficiency of production, it can be concluded that the set goal is achieved with both selling prices, which is more than $50 \%$.

\subsection{Comparison of results}

Table II provides an overview of the simulation results for the transition from the current individual production to lean series production. According to the AS IS state, two possibilities of transition were analysed: 1) to flow production and 2) to cell or line production.

Table II makes us conclude that only the transformation of the production process into cell or line production fully meets the set goals for the transition from individual to lean series production. For comparison, Table II also provides information on the time efficiency of production (sum of processing times / lead times), which is obtained by the VSM analysis. It can be concluded that this information is of no use in making decisions for the transition to lean production. The structure of value-added shares is also interesting (Table III).

Table II: Comparison of results of simulated transition.

\begin{tabular}{|c|c|c|c|c|c|}
\hline \multirow{3}{*}{$\begin{array}{l}\text { Quantity [pcs/month] } \\
\text { Selling price [€/piece] }\end{array}$} & \multirow{3}{*}{$\begin{array}{c}\text { AS IS state } \\
1500 \\
11\end{array}$} & \multicolumn{2}{|c|}{ Flow production } & \multicolumn{2}{|c|}{ Cell or line production } \\
\hline & & \multicolumn{2}{|c|}{80,000} & \multicolumn{2}{|c|}{80,000} \\
\hline & & 11 & 4 & 11 & 4 \\
\hline Total costs [€/piece $]$ & 10.36 & \multicolumn{2}{|c|}{2.22} & \multicolumn{2}{|c|}{1.82} \\
\hline Lead time [Wd] & 73.8 & \multicolumn{2}{|c|}{7.3} & \multicolumn{2}{|c|}{9.12} \\
\hline$O E E[\%]$ & 54 & \multicolumn{2}{|c|}{65} & \multicolumn{2}{|c|}{65} \\
\hline Economic efficiency [\%] & 6 & 80 & 44 & 83 & 55 \\
\hline Time efficiency [\%] & 0.057 & \multicolumn{2}{|c|}{0.075} & \multicolumn{2}{|c|}{0.060} \\
\hline
\end{tabular}

Table III: Value-added shares.

\begin{tabular}{|l|c|c|c|}
\hline Added values & AS IS state & Flow production & Cell or line production \\
\hline$C_{V A}[€(\%)]$ & $9.61(92.69 \%)$ & $1.67(75.22 \%)$ & $1.67(91.90 \%)$ \\
\hline$C_{N N V A}[€(\%)]$ & $0.153(1.48 \%)$ & $0.45(20.19 \%)$ & $0.044(2.44 \%)$ \\
\hline$C_{N V A}[€(\%)]$ & $0.6(5.83 \%)$ & $0.102(4.59 \%)$ & $0.1(5.66 \%)$ \\
\hline Sum $[€]$ & 10.36 & 2.22 & 1.82 \\
\hline
\end{tabular}

As can be seen from Table III, the percentages of added value are relatively high, but the total costs in the AS IS state are absolutely too high and would soon become higher than the selling price in the long run. It is also evident that the decision for a cell or line production is also the most appropriate decision in terms of shares of added value.

According to [18], the results achieved can also be shown in the cost-time profile (Fig. 7). It shows how radical the introduced changes were on the account of the reduced lead time and the overall production cost per product unit.

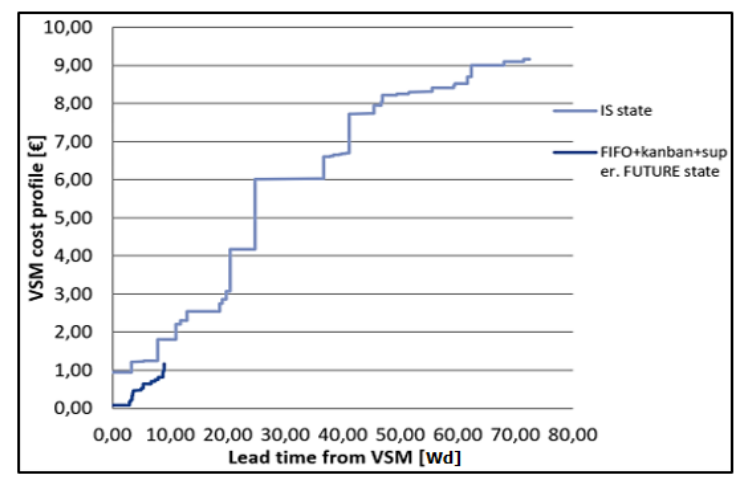

Figure 7: Cost-time profile. 
Fig. 7 shows that the flow time in the cost-time profile is reduced from $73.8 \mathrm{Wd}$ to $9.12 \mathrm{Wd}$, whereby the cost-profile of the product has decreased from $9.11 € /$ piece to $1.17 € /$ piece.

\section{CONCLUSION AND FURTHER WORK}

As the VSM analysis of the production process usually only provides data on the duration of individual operations and the total lead time, we decided to extend the usual VSM analysis with data on costs. Since the measures aimed at eliminating wastes are introduced gradually in improving the production process, we want to check the effects of these changes in terms of time (time VSM analysis) and cost (cost VSM analysis). In order to get an answer to the predicted change in real time, a simulation programme was created that converts data on operation times into costs through appropriate mathematical records. The result of such a simulation is the total production cost per product unit. In addition to the cost of materials and operations that add value, the total cost of the product may include other costs, such as the cost of using surfaces (due to warehousing and storing of work items before and after processing), the cost of binding capital into material and work performed, the costs of triggering orders and lots, indirect and overhead costs. To calculate economic efficiency, the ratio between profit (selling price - total cost) and selling price was used. Based on this quotient and known data on $O E E$, a portfolio analysis can be performed to determine the leanness of the production process. This, in turn, can support the decision of the company's management whether or not to implement the proposed change. Of course, the company's management must make a comprehensive investment assessment of the economy and profitability of the investment before making a final decision.

The proposed method for determining the leanness and agility of a production process based on the cost VSM and portfolio analysis and the simulation of the effects of improvements on the economic efficiency of the production system is certainly an important scientific contribution in the field of leanness as very few papers on this topic can be found in literature. Companies often see an increase in economic efficiency in investments in machinery and equipment and automation of the production process, but they must ask themselves whether the cost of the product will not be too high and thus bring a small profit or no profit at all. A response to such a question can be obtained using the proposed cost VSM method and portfolio analysis of leanness and agility. This is clearly illustrated by the case study. In the proposed method, the costs due to the binding of capital in the material and the work performed were calculated in relation to the total lead time, although this cost is incurred gradually. This, in turn, will be the subject of further research.

\section{REFERENCES}

[1] Teichgräber, U. K.; de Bucourt, M. (2012). Applying value stream mapping techniques to eliminate non-value-added waste for the procurement of endovascular stents, European Journal of Radiology, Vol. 81, No. 1, 47-52, doi:10.1016/j.ejrad.2010.12.045

[2] Rother, M.; Shook, J. (2003). Learning to See: Value - Stream Mapping to Add Value and Eliminate $M u d a$, Lean Enterprise Institute, Cambridge

[3] Heravi, G.; Firoozi, M. (2017). Production process improvement of buildings' prefabricated steel frames using value stream mapping, The International Journal of Advanced Manufacturing Technology, Vol. 89, 3307-3321, doi:10.1007/s00170-016-9306-9

[4] Lazarevic, M.; Mandic, J.; Sremcev, N.; Vukelic, D.; Debevec, M. (2019). A systematic literature review of poka-yoke and novel approach to theoretical aspects, Strojniski vestnik - Journal of Mechanical Engineering, Vol. 65, No. 7-8, 454-467, doi:10.5545/sv-jme.2019.6056

[5] Haider, A.; Mirza, J. (2015). An implementation of lean scheduling in a job shop environment, Advances in Production Engineering \& Management, Vol. 10, No. 1, 5-17, doi:10.14743/ apem2015.1.188 
[6] Kuhlang, P.; Edtmayr, T.; Sihn, W. (2011). Methodical approach to increase productivity and reduce lead time in assembly and production-logistic processes, CIRP Journal of Manufacturing Science and Technology, Vol. 4, No. 1, 24-32, doi:10.1016/j.cirpj.2011.02.001

[7] Gunduz, M.; Naser, A. F. (2017). Cost based value stream mapping as a sustainable construction tool for underground pipeline construction projects, Sustainability, Vol. 9, No. 12, Paper 2184, 20 pages, doi:10.3390/su9122184

[8] Kumar, S.; Dhingra, A. K.; Singh. B. (2018). Cost reduction by value stream mapping using LeanKaizen concept: a case study, International Journal of Productivity and Quality Management, Vol. 24, No. 1, 12-32, doi:10.1504/IJPQM.2018.091166

[9] Carmignani, G. (2017). Scrap value stream mapping (S-VSM): a new approach to improve the supply scrap management process, International Journal of Production Research, Vol. 55, No. 12, 3559-3576, doi:10.1080/00207543.2017.1308574

[10] Onofrejova, D.; Janekova, J.; Grincova, A.; Soltysova, Z. (2020). Simulation and evaluation of production factors in manufacturing of fireplaces, International Journal of Simulation Modelling, Vol. 19, No. 1, 77-88, doi:10.2507/IJSIMM19-1-504

[11] Urban, W. (2019). TOC implementation in a medium-scale manufacturing system with diverse product rooting, Production \& Manufacturing Research, Vol. 7, No. 1, 178-194, doi:10.1080/ 21693277.2019.1616002

[12] Koblasa, F.; Śírová, E.; Králíková, R. (2019). The use of process thinking in the industrial practice - Preliminary survey, Technical Gazette, Vol. 26, No. 3, 786-792, doi:10.17559/TV20150617135306

[13] Zhou, B.-H.; Liu, Y.-W.; Yu, J.-D.; Tao, D. (2018). Optimization of buffer allocation in unreliable production lines based on availability evaluation, Optimal Control Applications and Methods, Vol. 39, No. 1, 204-219, doi:10.1002/oca.2341

[14] Yang, S. L.; Xu, Z. G.; Wang, J. Y. (2019). Modelling and production configuration optimization for an assembly shop, International Journal of Simulation Modelling, Vol. 18, No. 2, 366-377, doi:10.2507/IJSIMM18(2)CO10

[15] Prester, J.; Buchmeister, B.; Palčič, I. (2018). Effects of advanced manufacturing technologies on manufacturing company performance, Strojniski vestnik - Journal of Mechanical Engineering, Vol. 64, No. 12, 763-771, doi:10.5545/sv-jme.2018.5476

[16] Ivanisevic, A.; Katic, I.; Buchmeister, B.; Leber, M. (2016). Business plan feedback for cost effective business processes, Advances in Production Engineering \& Management, Vol. 11, No. 3, 173-182, doi:10.14743/apem2016.3.218

[17] Stremcev, N.; Stevanov, B.; Lazarevic, M.; Mandic, J.; Tesic, Z.; Kuzmanovic, B. (2019). Improving process of quotation creation through value stream mapping and simulation, International Journal of Simulation Modelling, Vol. 18, No. 4, 563-573, doi:10.2507/ IJSIMM18(4)484

[18] Gracanin, D.; Buchmeister, B.; Lalic, B. (2013). Using cost-time profile for value stream optimization, Proceedings of the $24^{\text {th }}$ DAAAM International Symposium on Intelligent Manufacturing and Automation, 1225-1231

[19] Jordan, E.; Kušar, J.; Rihar, L.; Berlec, T. (2019). Portfolio analysis of a Lean Six Sigma production process, Central European Journal of Operations Research, Vol. 27, No. 3, 797-813, doi:10.1007/s10100-019-00613-4 